\title{
China's Practice in International Investment Law: From Participation to Leadership in the World Economy
}

\author{
Guiguo Wang ${ }^{\dagger}$
}

\section{INTRODUCTION}

This Essay is in honor of Professor Michael Reisman. I had the privilege of studying for a J.S.D. degree at Yale under his supervision. Professor Reisman is a great scholar of extreme modesty. He listens well, responds promptly to students' needs, and patiently explains his and others' viewpoints. Professor Reisman led me to the Yale Law School twenty-seven years ago, and ever since I have benefited from his great scholarship, and in particular his New Haven School jurisprudence-law "as a process of decision that is both authoritative and controlling." It is difficult to measure the extent to which my study of the law has benefited from Professor Reisman's scholarship. Yet I can safely say that his theory of, and approach to, the law have had a profound influence on my scholarship. This piece is a case in point. In fact, as with many of my earlier projects, I have again had the benefit of his advice in writing this Essay.

This brief Essay reviews the policies and laws adopted by China in the last three decades relating to foreign investment, in particular the recent development of China's policies regarding bilateral investment treaties (BITs) and free trade agreements (FTAs). China started its long march toward modernization in 1978 by encouraging the inflow of foreign capital and technology and reforming the domestic economy. ${ }^{2}$ Within thirty years, it has become the most active and largest developing host country for foreign direct investment ${ }^{3}$ and has entered into more than $120 \mathrm{BITs}^{4}$ and several FTAs, most

$\dagger \quad$ Dean and Professor of Chinese and Comparative Law, School of Law, City University of Hong Kong; Distinguished Professor of Law, Hunan University, China. Yale Law School, J.S.D. 1984; Columbia Law School, LL.M. 1982.

1. See W. Michael Reisman, Siegfried Wiessner \& Andrew R. Willard, Commentary, The New Haven School: A Brief Introduction, 32 YALE J. INT'L L. 575, 576 (2007).

2. After the death of Chairman Mao Zedong in 1976, Deng Xiaoping came to power. The Chinese Communist Party held a meeting at which it declared an end to both the notorious Cultural Revolution and the Party's large-scale political movement. It also announced that the country would embark on domestic economic reforms and open itself to the outside world. For more detailed discussion, see GuIGUO WANG, WANG'S Business LaW OF ChINA 5-11 (Kelleigh Poon ed., 4th ed. 2003).

3. According to statistics issued by the Ministry of Commerce, China had taken in $\$ 747.1$ billion in foreign investment by the end of November 2007. See China's Foreign-Capital Utilization in 2007, http://www.fdi.gov.cn/pub/FDI_EN/News/Focus/Subject/Utilization2007/default.html (last visited Apr. 1, 2009) [hereinafter China's Foreign-Capital Utilization].

4. See U.N. Conference on Trade and Dev. [UNCTAD], Recent Developments in International Investment Agreements: 2007-June 2008, at 3, fig.2, Doc. No. UNCTAD/WEB/ DIAE/IA/2008/1 (2008), available at http:/www.unctad.org/en/docs/webdiaeia20081_en.pdf. 
recently the China-New Zealand FTA concluded in April 2008. ${ }^{5}$ In appraising the gradual progress of the Chinese foreign investment legal regime, this Essay will emphasize the factors that have led to the changes in the system and the interactions between international and national norms. Although China has not been involved as a party to any dispute, Chinese practice in BITs and FTAs will have important consequences in shaping disputes and thus will also be reviewed.

In this Essay, four main areas will be examined: (1) treatment of investment; (2) qualified investments and investors; (3) expropriation; and (4) investor-state dispute settlement. The last Part will propose a policy alternative-namely, the development of a model BIT.

\section{MECHANISMS FOR PROTECTING FOREIGN INVESTMENT}

China adopted the Chinese-Foreign Equity Joint Ventures Law ${ }^{6}$ in 1979 for the purpose of attracting foreign investment. This law was followed, almost ten years later, by the Chinese-Foreign Contractual Joint Ventures Law $^{7}$ and the Wholly Foreign-Owned Enterprises Law. ${ }^{8}$

These three laws have dictated the forms of foreign investment in China. ${ }^{9}$ In general, there is no upper limit on foreign equity holdings, while the minimum ownership of foreign investors is twenty-five percent of the total investment. ${ }^{10}$ After China joined the World Trade Organization (WTO), a number of additional economic sectors became open to foreign investments. ${ }^{11}$

A very important issue in China's effort to attract foreign investment has been its treatment of foreign investors, in particular with respect to the issues of expropriation, compensation, and the standard of compensation. ${ }^{12}$ China has tried to ease foreign investors' concerns about expropriation through both

5. Free Trade Agreement, P.R.C.-N.Z., art. 135, Apr. 7, 2008, available at http://chinafta. govt.nz/1-The-agreement/2-Text-of-the-agreement/0-downloads/NZ-ChinaFTA-Agreement-text.pdf [hereinafter China-New Zealand 2008 FTA].

6. Law on Chinese-Foreign Equity Joint Ventures (promulgated by the Fifth Nat'l People's Cong., July 1, 1979, amended by the Standing Comm. Nat'l People's Cong., Mar. 15, 2001), translated in ISINOLAW (last visited Apr. 2, 2009) (P.R.C.).

7. Law on Chinese-Foreign Contractual Joint Ventures (promulgated by Standing Comm. Nat'l People's Cong., Apr. 13, 1988, amended by the Standing Comm. Nat'l People's Cong., Oct. 31, 2000), translated in IsINOLAW (last visited Apr. 2, 2009) (P.R.C.).

8. Law on Wholly Foreign-Owned Enterprises (promulgated by the Sixth Nat'l People's Cong., Apr. 12, 1986, amended by the Standing Comm. Nat'l People's Cong., Oct. 31, 2000), translated in ISINOLAW (last visited Apr. 2, 2009) (P.R.C). For discussion on these laws and their implementation, see WANG, supra note 2, at 193-247.

9. According to China's Ministry of Commerce, by the end of 2007, more than 630,000 foreign-invested enterprises had been established. See China's Foreign-Capital Utilization, supra note 3.

10. Article 4 of the Law on Chinese-Foreign Equity Joint Ventures provides in respect of the registered capital of a joint venture that "[t]he proportion of the foreign joint venture party's investment . . . shall be, in principle, not less than 25 percent of its registered capital." Law on ChineseForeign Equity Joint Ventures, supra note 6, art. 4.

11. For discussion on the matter, see GuIguO WANG, THE LAW OF THE WTO: CHINA AND THE FutTURE OF FREE TRADE 51-55 (2005).

12. These questions arose because, after the establishment of the People's Republic in 1949 , China expropriated all private enterprise, a process that ended in 1957 when the Anti-Rightists Movement began. 
domestic laws ${ }^{13}$ and BITs. The first group of BITs that China entered into included treaties with Germany (1983), France (1984), and Norway (1984). They are brief in nature, outlining the desire of the parties to promote bilateral investment. They also emphasize the right of subrogation in case of expropriation and repatriation of investment. While most-favored-nation (MFN) treatment ${ }^{14}$ is provided in those treaties, national treatment ${ }^{15}$ was not granted to foreign investors and investments.

As China has gained more experience with foreign investment, further improvements have been made. For instance, the early BITs tended to define investments narrowly and would only grant foreign investors MFN treatment. In the current generation of BITs, however, elements such as national treatment, fair and equitable treatment, full security and protection according to international standards, as well as investor-state arbitration, are included as standard provisions. In addition, on February 6, 1993, China became a contracting party to the ICSID Convention; ${ }^{16}$ however, it made a reservation that it "would only consider submitting to the jurisdiction of ICSID disputes over compensation resulting from expropriation or nationalization." 17

More recently, China renegotiated and signed BITs with Germany (December 2003), Finland (November 2004), Spain (November 2005), and Portugal (December 2005). These newly revised BITs reflect the Chinese government's current position on international investment law. They constitute a new generation of Chinese BITs.

The FTAs to which China is a party are also important factors for foreign investment. The first FTA negotiated by China was with the Association of Southeast Asian Nations (ASEAN) in November 2002, ${ }^{18}$ followed by the China-Chile FTA, ${ }^{19}$ both of which concentrate essentially on

13. For instance, Article 2 of the Law on Chinese-Foreign Equity Joint Ventures provides: "The State shall not nationalize or requisition any equity joint ventures. Under special circumstances, when public interest requires, equity joint ventures may be requisitioned by following legal procedures and appropriate compensation shall be made." Law on Chinese-Foreign Equity Joint Ventures, supra note 6 , art. 2 .

14. According to the International Law Commission, "[m]ost-favored-nation treatment is treatment accorded by the granting State to the beneficiary State, or to persons or things in a determined relationship with that State, not less favorable than treatment extended by the granting State to a third State or to persons or things in the same relationship with that third State." Int'l Law Comm'n, Draft Articles on Most-Favored-Nation Clauses, [1978] 2 Y.B. Int'l L. Comm'n pt. 2, at 21, U.N. Doc. A/CN.4/SER.A/1978/Add.1. In practice, MFN treatment may cover any advantage, favor, privilege, or immunity in relation to investment, trade in goods and services, intellectual property protection, etc.

15. Like MFN treatment, national treatment is also a treaty obligation whereby the granting State undertakes to accord treatment "of persons or things in a determined relationship with the beneficiary State, not less favorable than the treatment of persons or things in the same relationship with itself." See Int'l Law Comm'n, Fifth Report on the Most-Favored-Nation Clause by Mr. Endre Ustor, Special Rapporteur-Draft Articles with Commentaries (Continued), [1974] 2 Y.B. Int'l L. Comm'n pt. 1, at 124, U.N. Doc. No. A/CN.4/280.

16. Convention on the Settlement of Investment Disputes Between States and Nationals of Other States, Mar. 18, 1965, 17 U.S.T. 1270, 575 U.N.T.S. 159.

17. The reservation made by China was considered by some to reflect its reluctance to submit disputes to international arbitration. See Mark A. Cymrot, Investment Disputes with China, DiSP. RESOL. J., Aug.-Oct. 2006, at 80.

18. Framework Agreement on Comprehensive Economic Co-operation, P.R.C.-ASEAN, Nov. 5, 2002, available at http:/www.aseansec.org/13196.htm.

19. Free Trade Agreement, P.R.C.-Chile, Nov. 18, 2005, available at http://www.direcon.cl/ documentos/China2/tlc_chile_china_ing_junio_2006.pdf. 
trade issues. The most comprehensive FTA that China has entered into is with New Zealand, ${ }^{20}$ which was signed following the China-Pakistan FTA. ${ }^{21}$

\section{QUALIFIED INVESTMENTS AND INVESTORS}

Qualified investments and investors are essential for the enjoyment of protection under BITs and FTAs. In this regard, the China-Norway BIT, one of the earliest Chinese BITs, provides that " $[$ t]he term 'investing' means assets permitted by either contracting party in accordance with its laws and regulations, including" movable and immovable properties, shares, stocks and debentures, claims to money, copyrights, and concessions conferred by law. ${ }^{22}$

The definition of investment has broadened with the development of Chinese law and China's increased experience with investment treaties. For instance, the 2003 China-Germany BIT defines investment as "every kind of asset invested directly or indirectly by investors of one Contracting Party in the territory of the other Contracting Party."23 By including the word "indirectly," the China-Germany BIT covers a broader set of investments than those covered by China's previous BITs. The China-New Zealand FTA specifically includes in the definition of investment "bonds, including government issued bonds, debentures, loans and other forms of debt, and rights derived therefrom," and "any right conferred by law or under contract and any licenses and permits pursuant to law." 24

Following international practice, the BITs and FTAs that China has entered into identify many different areas and activities as "investment." As a consequence, what constitutes an investment may be subject to interpretation in practice. Indeed, the ambiguity of this term is often the source of investment disputes in the international arena. In this regard, China would welcome the "Salini test," according to which any foreign direct investment should contribute to the economic development of the host country. ${ }^{25}$

Chinese law also requires foreign investors to contribute advanced technology that will, in China's view, contribute to economic development. ${ }^{26}$ Suppose the Chinese government, after examining the documents and business plans of foreign investors, approves a project, but later determines

20. China-New Zealand 2008 FTA, supra note 5.

21. Free Trade Agreement, P.R.C.-Pak., Nov. 24, 2006, available at http://gjs.mofcom.gov.cn/ accessory/200611/1164349025774.doc [hereinafter China-Pakistan 2006 FTA].

22. Agreement on Mutual Protection of Investments, P.R.C.-Nor., art. 1, Mar. 1, 1987, available at http://www.unctad.org/sections/dite/iia/docs/bits/china_norway.pdf [hereinafter ChinaNorway 1987 BIT].

23. Agreement on the Encouragement and Reciprocal Protection of Investments, P.R.C.F.R.G., art. 1, Dec. 1, 2003, available at http://www.unctad.org/sections/dite/iia/docs/bits/china germany.pdf [hereinafter China-Germany 2003 BIT].

24. China-New Zealand 2008 FTA, supra note 5, art. 135.

25. See Salini Costruttori S.p.A. v. Morocco, ICSID Case No. ARB/00/4, Decision on Jurisdiction (July 23, 2001), 42 I.L.M. 609 (2003). But see L.E.S.I., S.p.A. v. Algeria, ICSID Case No. $\mathrm{ARB} / 05 / 3$, Decision on Jurisdiction para. 72 (July 12,2006 ), available at $\mathrm{http}: / /$ ita.law.uvic.ca/documents/LESIAlgeria.pdf (emphasizing that Salini is one in a group of cases that have weighed in on the issue).

26. Law on Chinese-Foreign Equity Joint Ventures, supra note 6, art. 5 ("The technology and equipment contributed by a foreign joint venture party as its investment must be . . . advanced technology and equipment that suit China's needs."). 
that the investment is not qualified to enjoy preferential treatment because the technology invested is insufficiently advanced. In this case, the tribunals seized of the case would need to decide the qualification of the investment, ${ }^{27}$ and the relevant BIT may play a crucial role.

The BITs China entered into before the mid-1990s all require investments to be made "in accordance with the laws and regulations" of the host country. The recently concluded BITs, however, do not include such a requirement. For example, the new China-Germany BIT simply defines investment as "every kind of asset invested directly or indirectly." 28 In practice, this omission may prevent China from claiming that an investment is unqualified and therefore lacks the protection of the treaty, as the Philippine government did in the Fraport case. ${ }^{29}$

The approval processes in relation to foreign investment may work for China as a recipient of foreign capital where a foreign investor fails to fully disclose the information required by law. The case in point is Plama $v$. Bulgaria ${ }^{30}$ in which the foreign investor failed to make a full disclosure of its shareholding. The tribunal held the concealment as "amounting to fraud, calculated to induce the Bulgarian authorities to authorize the transfer of shares to an entity that did not have the financial and managerial capacities required.",3i

With regard to defining the category of "investors," which is another fundamental question in international investment law, the China-New Zealand FTA contains a typical statement affording protection to enterprise investors "constituted or organized under the law of a Party, and a subsidiary located in the territory of a Party and engaged in substantive business operations there." 32 A plain reading of the above provision would mean that where an entity from one party sets up an enterprise (subsidiary) in the territory of the other party, the subsidiary may not be entitled to the treaty protection unless it engages in substantive business activities. This provision may not cover natural persons, notwithstanding Article 149(b), which permits a Contracting Party to deny the benefits to "investors of the other Party where the investment is being made by an enterprise that is owned or controlled by persons of the denying Party and the enterprise has no substantive business operations in the territory of the other Party." 33 Without a doubt, the word "persons" covers both legal and natural persons. ${ }^{34}$ The essence of these

27. In Saipem, the ICSID tribunal reiterated the investor's claim that because "'Saipem invested substantial technical, financial and human resources in the project, which gave a substantial contribution to Bangladesh's economic development, and it assumed risks for a significant duration,"' the related contract was an investment. Saipem S.p.A. v. Bangladesh, ICSID Case No. ARB/05/07, Decision on Jurisdiction, para. 100 (Mar. 21, 2007), available at http://ita.law.uvic.ca/documents/ Saipem-Bangladesh-Jurisdiction.pdf.

28. China-Germany 2003 BIT, supra note 23, art. 1(1).

29. Fraport AG Frankfurt Airport Servs. Worldwide v. Philippines, ICSID Case No. ARB/03/25, Award (Aug. 16, 2007), available at http://ita.law.uvic.ca/documents/FraportAward.pdf.

30. Plama Consortium Ltd. v. Bulgaria, ICSID Case No. ARB/03/24, Award (Aug. 27, 2008), available at http://ita.law.uvic.ca/documents/PlamaBulgariaAward.pdf.

31. Id. para. 135 .

32. China-New Zealand 2008 FTA, supra note 5, art. 135. "Natural person" investors covered by the treaty include nationals and permanent residents of either state party to the agreement. $I d$.

33. Id. art. 149(b).

34. Id. art. 4. 
provisions is to prevent a Tokios Tokeles situation, ${ }^{35}$ wherein the control test was held not to apply in determining the nationality of foreign investors.

\section{TREATMENT OF INVESTMENT}

To hold the host government responsible under a BIT, the body that acts or fails to act must be part of the government. BITs, however, seldom explicitly identify the agencies whose actions can or cannot be attributed to the state. In practice, such issues are determined in accordance with international law--in particular, customary international law. The Draft Articles on Responsibilities of States for Internationally Wrongful Acts ${ }^{36}$ adopted in 2001 by the International Law Commission are often referred to.

Insofar as a treatment standard is concerned, around twenty percent of the BITs that China has entered into provide for national treatment. ${ }^{37}$ Most of its recently concluded BITs contain relative standards-national and MFN treatment, as well as the fair and equitable standard. The China-Germany BIT provides that such standards should apply to "investments and activities associated with such investments, ${ }^{38}$ but it is far from clear as to what may constitute an activity associated with or relating to an investment. The Protocol to the China-Germany BIT further sets out that "the following shall more particularly, though not exclusively, be deemed 'activity' within the meaning of Article 3(2): the management, maintenance, use, enjoyment and disposal of an investment." 39 In any event, the phrase, "though not exclusively," should be read to imply the inclusion of any activity that may be reasonably justified as related to an investment. Of course, a question that may immediately arise is whether the national and MFN treatment under the BIT could be applied to preinvestment activities. ${ }^{40}$

Concerning the treatment standards, the China-Portugal BIT, like several other BITs, makes a reference to international law. Article 10(1) states:

35. Tokios Tokeles v. Ukraine, ICSID Case No. ARB/02/18, Decision on Jurisdiction (June 29, 2007), available at http://icsid.worldbank.org/ICSID (follow "Cases").

36. See Int'l L. Comm'n, Draft Articles on Responsibility of States for Internationally Wrongful Acts, in Report of the International Law Commission to the General Assembly, 56 U.N. GAOR Supp. (No. 10) at 43, U.N. Doc. A/56/10 (2001), reprinted in [2001] 2 Y.B. Int'l L. Comm'n pt. 2 at 20,47-49, 52-54, U.N. Doc. A/CN.4/SER.A/2001/Add.1.

37. Among the 117 BITs China has entered into so far, only seventeen provide for national treatment, whilst the others stipulate fair and equitable treatment as the standard. See Zhang Caixia, Shenshi yu chonggou zhongwai shuangbian touzi xiedingzhong de guomin daiyu zhidu [Review and Reestablish the National Treatment System in Sino-Foreign BITs], 5 FALUN LUNTAN [RULE OF LAW TRIB.] 240 (2007).

38. China-Germany 2003 BIT, supra note 23, art. 3(2).

39. Protocol to the Agreement on the Encouragement and Reciprocal Protection of Investments, P.R.C.-F.R.G., para. 4, Dec. 1, 2003, available at http://www.unctad.org/sections/dite/iia/ docs/bits/china_germany.pdf.

40. Chinese law contains no provisions for affording pre-investment national treatment to foreign investors. China is now an observer of the Energy Charter Treaty, which stipulates national treatment to pre-investment activities. See Energy Charter Treaty pmbl. \& art. 10, Dec. 17, 1994, 34 I.L.M. 381 (1995), reprinted in ENERGY CHARTER SECRETARIAT, THE ENERgY CHARTER TREATY AND RELATED DOCUMENTS: A LEGAL FRAMEWORK FOR INTERNATIONAL ENERGY COOPERATION (2004), available at http://www.encharter.org/fileadmin/user_upload/document/EN.pdf. It is therefore foreseeable that China may come to accept pre-investment national treatment in its BITs. 
If the provisions of law of either Contracting Party or obligations under international law existing at present or established hereafter between the Contracting Parties in addition to the present Agreement contain regulations entitling investments by investors of the other Contracting Party to a treatment more favorable than is provided for by the present Agreement, such regulations shall, to the extent that they are more favorable, prevail over the present Agreement. ${ }^{41}$

These provisions may raise more questions than they resolve, as what may constitute the appropriate international standard is, to say the least, very uncertain. ${ }^{42}$

As discussed earlier, in China's practice, the protection and treatment offered to investors, both national and MFN, are without qualification. This is in contrast to the "prudential reasons" exception under Article 1410(1) of the North American Free Trade Agreement ${ }^{43}$ (NAFTA), which is limited to measures directed at protecting the integrity of the financial system. ${ }^{44} \mathrm{~A}$ similar provision was included in China's specific commitments relating to the service sector that were made for purposes of joining the WTO. As it is very difficult, if not impossible, to draw a line between investment and trade in services in most cases, this may cause difficulties in practice. For instance, where a measure is introduced by the Chinese government pursuant to the prudential principle under the General Agreement on Trade in Services (GATS), it may be judged against the provisions of BITs relating to fair and equitable treatment and national treatment. As the WTO dispute resolution mechanisms only permit WTO members to initiate complaints, private investors are likely to choose international arbitration for resolving their disputes with China. In such a case, may the Chinese government use GATS compliance as a defense for not providing fair and equitable treatment or national treatment to foreign investors?

"Fair and equitable treatment" has become a common treatment standard in China's recent BITs. The China-New Zealand FTA, as a matter of principle, does not apply to trade in services. Yet it extends to government measures that affect the supply of services through commercial presence in respect to transfer of funds, fair and equitable treatment, compensation, expropriation, and subrogation. In such matters, a service supplier may invoke the investorstate dispute settlement mechanism to resolve its differences with the host government. ${ }^{45}$ Constant protection and security are also commonly provided

41. Agreement Concerning the Encouragement and Reciprocal Protection of Investments, P.R.C.-Port. art. 10(1), Feb. 3, 1992, available at http://www.chinahotelsreservation.com/china_law/ Agreement_between_china_law_the_Government526.html [hereinafter China-Portugal 1992 BIT].

42. The Neer case is generally regarded as the historical baseline standard for the treatment for foreigners. See Neer v. Mexico, 4 R. Int'l Arb. Awards 60 (U.S.-Mex Gen. Claims Comm'n 1926). However, some tribunals have since departed from the Neer standard and held that the minimum standard has evolved over time. See, e.g., ADF Group, Inc. v. United States, ICSID Case No. ARB(AF)/00/1, Award, para. 179 (Jan. 9, 2003), available at http://www.state.gov/documents/ organization/16586.pdf.

43. Fireman's Fund Ins. Co. v. Mexico, ICSID Case No. ARB(AF)!02/01, Award, paras. 15668 (July 17, 2006), available at http://icsid.worldbank.org/ICSID (follow "Cases").

44. See Olin L. Wethington, Financial Market liberalization: The Nafta FRAMEWORK 74-75 (1994).

45. China-New Zealand 2008 FTA, supra note 5, art. 137. The measures affecting services do not include subsidies provided by a party or "laws, regulations, policies or procedures of general application governing the procurement by government agencies of goods and services purchased for 
in China's BITs and therefore they have become standard treatments that China offers to foreign investors.

There are also restraints on the application of national treatment provisions. They include (1) the existing nonconforming measures, (2) continuation and amendments of nonconforming measures provided that such amendments do not increase the degree of nonconformity, and (3) a measure that would not fall into the national treatment obligations under an existing bilateral investment treaty that a party has concluded. ${ }^{46}$ This having been stipulated, the parties are under an obligation to progressively remove the nonconforming measures. ${ }^{47}$

The China-New Zealand FTA also stipulates that the FTA's condition regarding most favored nation treatment "does not encompass a requirement to extend to investors of the other Party dispute resolution procedures other than those set out" in the FTA, ${ }^{48}$ nor does the FTA prevent the parties from "accord[ing] differential treatment to third countries under any free trade agreement or multilateral international agreement." 49 Differential treatment involving fisheries and maritime matters under international agreements may also be considered an exception to the MFN treatment. ${ }^{50}$

\section{EXPROPRIATION AND COMPENSATION}

Large-scale expropriation is no longer a major threat to contemporary international investment. However, indirect and creeping expropriation often triggers disputes. As one of the host countries that has attracted the largest amount of foreign capital, China has always paid particular attention to the issue of expropriation. For instance, the China-Norway BIT stipulates that expropriations of foreign direct investments must serve a public purpose ${ }^{51}$ and be carried out in a nondiscriminatory manner. ${ }^{52}$ The China-New Zealand FTA also provides that expropriation must "not [be] contrary to any undertaking which the Party may have given., 53

With regard to compensation for expropriation, most recent BITs to which China is a party allow expropriation only upon the satisfaction of certain conditions. Nearly all of these BITs contain some form of the following provision:

govermmental purposes and not with a view to commercial resale or with a view to use in the production of goods or the supply of services for commercial sale." Id.

46. Id. art. 141 .

47. Id. The China-New Zealand FTA does not provide specifically what may constitute a nonconforming measure. It instead incorporates the provisions of the WTO Agreement on TradeRelated Investment Measures (TRIMs) mutatis mutandis. See Agreement on Trade-Related Investment Measures, Apr. 15, 1994, Marrakesh Agreement Establishing the World Trade Organization, Annex 2, Legal Instruments-Results of the Uruguay Round, 33 I.L.M. 1125 (1994).

48. China-New Zealand 2008 FTA, supra note 5, art. 139(2).

49. Id. art. 139(3). This exception also includes, "in respect of agreements on the liberalisation of trade in goods or services or investment, any measures taken as part of a wider process of economic integration or trade liberalisation between the parties to such agreements." Id. art. 139(4).

50. Id. art. 139(5).

51. China-Norway 1987 BIT, supra note 22 , art. 5(1).

52. Id.

53. China-New Zealand 2008 FTA, supra note 5, ant. 145(1)(d). 
Neither Contracting Party shall expropriate, nationalise or take other measures having similar effects ... against the investments of the investors of the other Contracting Party in its territory, unless the following conditions are met. The expropriation is done:
(a) in the public interest;
(b) under domestic legal procedure;
(c) without discrimination, and
(d) against compensation. ${ }^{54}$

Without exception, all of the above-mentioned BITs contain clauses stipulating that compensation must be paid without undue delay, including interest, in a form that is effective and freely transferable. These provisions are in essence a reflection of the "Hull Rule": the host state is required to pay prompt, adequate, and effective compensation in case of expropriation. These provisions of the recent Chinese BITs confirm that China has accepted the standard. None of these BITs, however, contain detailed rules regarding how the market value should be ascertained, whether the discounted cash flow method could be employed, whether the expected profits should be compensated, and what may constitute expected profits. ${ }^{56}$ Such issues will have to be addressed by arbitral tribunals or the courts. It will be interesting to observe how international investment arbitration and treaty practice may affect interpretation of these BITs with China.

All of the recent Chinese BITs contain rules on indirect expropriation through their reference to "other measures having similar effects," resembles language in NAFTA. ${ }^{58}$ However, this language offers little guidance as to which specific measures constitute indirect or creeping expropriation.

China now accepts fair market value as the standard for compensation, although the wording may differ from treaty to treaty. ${ }^{59}$ For example, the China-New Zealand FTA contains detailed provisions on the calculation of compensation by stating that where "the fair market value is denominated in a freely usable currency," 60 the compensation must be ascertained in accordance

54. Agreement on the Encouragement and Reciprocal Protection of Investments, P.R.C.-Fin., art. 4(1), Mar. 10, 2006, available at http://www.unctad.org/sections/dite/iia/docs/bits/china_finland.pdf [hereinafter China-Finland 2006 BIT]; see, e.g., China-Portugal $1992 \mathrm{BIT}$, supra note 41, art. 4(1); Acuerdo para la Promoción y Fomento Recíprocos de Inversiones [Agreement on the Encouragement and Reciprocal Protection of Investments], P.R.C.-Spain, art. 4(1), Feb. 6, 1992, available at http://www.unctad.org/sections/dite/iia/docs/bits/spain_china_sp.pdf.

55. The Hull Rule was articulated in 1938 by U.S. Secretary of State Cordell Hull in response to Mexican expropriation of U.S. agricultural and oil interests. It became the cardinal principle of U.S. custom in this sphere. See M. SorNarajah, The INTERNATIONAL LAW ON ForeIgN INVESTMENT 128 (1994).

56. On the issue of expected profits, see CME Czech Rep. B.V. v. Czech Republic, Award, Separate Opinion on the Issues at the Quantum Phase, para. 32 (Mar. 14, 2003) (Brownlie, Arb.), available at http://ita.law.uvic.ca/documents/CME2003-SeparateOpinion_000.pdf.

57. China-Finland 2006 BIT, supra note 54, art. 4(1); see also China-Germany 2003 BIT, supra note 23, art. 4(2); China-Portugal 1992 BIT, supra note 41, art. 4(1).

58. North American Free Trade Agreement, U.S.-Can.-Mex., art. 1110, Dec. 17, 1992, 107 Stat. 2057, 32 I.L.M. 289.

59. For instance, the China-Pakistan FTA requires compensation to be equivalent to the value of the expropriated investments immediately before the expropriation or before the impending expropriation becomes public knowledge, whichever occurs earlier. China-Pakistan 2006 FTA, supra note 21 , art. 49.

60. According to the International Monetary Fund, U.S. dollars, Japanese yen, British pounds sterling, and the Euro are freely usable currencies. Selected Decisions and Selected Documents of the IMF, Thirtieth Issue-Freely Usable Currencies, Decision No. 11857-(98/130) (June 30, 2006), available at $\mathrm{http}: / / \mathrm{www}$.imf.org/external/pubs/ft/sd/index.asp?decision=11857-(98/130). 
with the "fair market value on the date of expropriation, plus interest at a commercially reasonable rate for that currency, accrued from the date of expropriation until the date of payment." ${ }^{\prime 61}$ In case the fair market value is denominated in a nonfreely usable currency, the compensation should be calculated at the prevailing market exchange rate for a freely usable currency on the date of payment. ${ }^{62}$

\section{INVESTOR-STATE DISPUTE SETTLEMENT}

The dispute settlement mechanism specified in China's earlier BITs usually excluded the jurisdiction of the International Centre for Settlement of Investment Disputes (ICSID). BITs that permitted ICSID jurisdiction limited this jurisdiction to disputes over expropriation and compensation.

This practice has changed dramatically in recent years. In 1998, China entered into a BIT with Barbados whereby disputes between a foreign investor and the host state may be submitted to the ICSID for arbitration. ${ }^{63}$ Similar provisions are found in other recent BITs to which China is a party. These BITs do not exclude the jurisdiction of the ICSID in relation to many important issues, including: denial of benefits to foreign investors; foreign investors with capital from the host country, or controlled or owned by domestic entities of the host country; prudent financial supervisory measures adopted by the host country; and significant safety exceptions. Such changes in Chinese treaty practice have much to do with the fact that an increasing number of Chinese entities are investing overseas. In order to protect Chinese nationals investing overseas, it is necessary for China to accept investor-state arbitration as a norm of international investment law.

The China-Pakistan FTA and the China-New Zealand FTA also provide for investor-state arbitration. Both FTAs make attempts at amicable settlement through negotiation a prerequisite for submission of a dispute for international arbitration. If the dispute cannot be settled within a period of six months, the investors concerned may decide to submit their dispute through other means. ${ }^{64}$ Under the China-Pakistan FTA, the investor may instead choose either to submit its dispute to a competent domestic court of the host country, or to arbitration at the ICSID; once a local court is chosen, submitting the same dispute to the ICSID for arbitration is precluded. ${ }^{65}$ The China-New Zealand FTA also authorizes investors to make use of ICSID conciliation or UNCITRAL arbitration procedures. ${ }^{66}$ Before availing themselves of international arbitration, they must give three months advanced notice to the

61. China-New Zealand 2008 FTA, supra note 5, art. 145(3).

62. Id. art. 145(4). The same applies to interest payment but "does not apply to the issuance of compulsory licenses granted in relation to intellectual property rights in accordance with the TRIPs Agreement." Id. art. 145(5).

63. Agreement on the Encouragement and Reciprocal Protection of Investments, P.R.C.Barbados, art. 8, July 20, 1998, available at http://www.asianlii.org/cn/legis/cen/laws/ abtgotprocatgobctearpoi 1447.

64. See China-New Zealand 2008 FTA, supra note 5, arts. 152-53; China-Pakistan 2006 FTA, supra note 21 , art. 54(1)-(2).

65. China-Pakistan 2006 FTA, supra note 21 , art. 54(2).

66. China-New Zealand 2008 FTA, supra note 5, art. 153(2). 
state party. ${ }^{67}$ The purpose of this provision is to allow the host country to require the use of administrative review procedures that already exist in the host country. ${ }^{68}$ The administrative review process in any event may not exceed three months.

Host countries always encourage investors to submit their disputes to local courts, but investors in most cases prefer international arbitration. Under the China-New Zealand FTA, an investor that has submitted its dispute to a local court of the host country may later decide to resort to international arbitration, provided that it has withdrawn its case from the local court before a final judgment is reached. ${ }^{69}$ This arrangement stands in contrast to that established under the China-Pakistan FTA.

The China-New Zealand FTA also has detailed rules on arbitration procedures that have the effect of modifying the domestic laws of the Parties as well as the normal procedures of the ICSID.$^{70}$ One such modification is that the statute of limitations for the submission of disputes must be within three years from "the time at which the disputing investor became aware, or should reasonably have become aware, of a breach of obligation" by the host country, which has "caus[ed] loss or damage to the investor or its investments."

With growing recognition of the need for government accountability in arbitration proceedings, the China-New Zealand FTA permits a state party to make publicly available all documents relating to arbitration, except those specifically designated as confidential when submitted to the arbitral tribunal. $^{72}$

\section{ALTERNATIVES FOR POLICY CONSIDERATION}

Over the last thirty years, China has gradually become the largest recipient of international investment among emerging market economies as well as a sizable capital-exporting country. It has come to accept the contemporary practices of the international community relating to international investment, and the Chinese legal system has become, in a relatively short period of time, much more conducive to the inflow of foreign capital.

Nevertheless, to play a role in world affairs commensurate to its size and economic importance, particularly in international investment, China still has much to do. In our highly globalized world, the line dividing national and international legal systems is becoming thinner; international norms are, by way of treaties like BITs and international organizations like the WTO, moving steadily and continuously into the legal system of sovereign states. States need to review and modify their laws and policies rapidly in order to cope with the ever-changing situation. After joining the WTO, China has been

67. Id. art. $153(1)$.

68. Id. art. $153(2)$

69. Id. art. 153(3).

70. Article 153(4) of the China-New Zealand FTA clearly states that the provisions of the FTA on dispute settlement prevails over both ICSID and UNCITRAL arbitration and conciliation procedures. Id. art. 153(4).

71. Id. art. 154(1)

72. Id. art. 157 . 
particularly active in revising its laws. Yet it appears that equal attention has not been paid to BITs.

China is already an important country in terms of both investment inflow and outflow. As it wishes to be viewed as a responsible member of the international community, however, it must do more to meet the rest of the world's expectations. This was put well by Professor Reisman: "Major power differential responsibilities form the very structure of the international economic agencies, for those agencies are premised on the transfer of resources by the wealthiest States to the less endowed States. Power within the agencies is distributed on the basis of the size of contributions." ${ }^{, 73}$ BITs and FTAs are integral parts of this international economic infrastructure, and China should do more to participate in their evolution and development.

One means through which China could exercise leadership would be to prepare a model BIT ("Chinese Model BIT"). To be sure, the Chinese government may already rely on internal draft models or precedents; what is currently lacking, however, is a publicly announced, and more detailed and comprehensive draft. The Chinese Model BIT would serve not only as a basis for future negotiations but also as a signal of the government's policy intentions that would in turn offer more predictability and transparency to state party counterparts and foreign investors alike. The Chinese Model BIT should address all the important issues, including:

- Conditions on qualified investments and investors. The Chinese Model BIT should stipulate clearly the Chinese position on this issue, in particular whether investments must be made in accordance with Chinese law.

- The relationship between fair and equitable treatment and international minimum standards of treatment. In practice, BITs and arbitral tribunals sometimes distinguish one from the other and sometimes treat these two standards as identical. It would be a significant contribution to international investment law if the Chinese Model BIT addressed this issue.

- Contents and standards of fair and equitable treatment. It is generally accepted that the fair and equitable treatment standard requires the host government to observe due process. The existence of a transparent body that is independent from the administrative authorities and empowered to handle disputes between the government and foreign investors may also be necessary in order to provide fair and equitable treatment to foreign investors. As this area of law is still developing, the more detailed the provisions are, the more impact they will have on the development of international investment law.

- Indirect expropriation. Most expropriation disputes involve indirect forms of expropriation, such as regulatory expropriation. These kind of disputes are the greatest source of trouble for host governments. The

73. W. Michael Reisman, Towards a Normative Theory of Differential Responsibility for International Security Functions: Responsibilities of Major Powers, in JAPAN AND INTERNATIONAL LAw: PAST, PRESENT AND FUTURE 43, 55 (Nisuke Ando ed., 1999). 
Chinese Model BIT should have well-thought-out provisions as to the exceptions to fair and equitable treatment, full protection and security, and international minimum standards in situations of emergency.

- Acts attributable to the host government. Where a BIT provides for the standard of treatment, etc., both acts and omissions must be attributable to the host government. In the Chinese context, despite the fact that China is gradually adopting a market-oriented economy, the government is still able to intervene in business transactions either directly or through quasi-governmental organizations. Professional and business associations may be closely connected with the government. To provide some clarity, the Chinese Model BIT may stipulate the parameters of acts and omissions attributable to the government, even though developing an exhaustive list may not be possible.

- Investor-state dispute resolution. The Chinese Model BIT should also deal with the effect of China's reservation to the ICSID Convention, and, in particular, address whether the principle of lex posterior derogate priori should apply. Another issue is whether the MFN principle applies to issues relating to dispute resolution.

- Interpretation rules. To negotiate a good treaty is only half the work; it must also be effectively implemented. The Chinese Model BIT should lay down some guiding principles and rules relating to interpretation.

Before drafting a Model BIT, the Chinese government should conduct systematic research on each of the issues involved. The Korean government has, for example, planned to mobilize scholars both within and outside the country to conduct research on investor-state arbitration. Research should also be undertaken into how to coordinate and harmonize present and future BITs and FTAs. China has entered into a framework agreement with ASEAN for the formation of a free trade area; negotiations on the detailed provisions are being conducted. At the same time, ASEAN countries are also interested in serving as the hub for the East Asian Community, which in their view is bound to take place. Good research will also help the Chinese government avoid the auto-parts type of problems that it has encountered in the WTO. ${ }^{74}$ In the process, as this brief Essay indicates, it is important to adopt the New Haven School approach articulated by Professor Reisman, i.e., the "praxis of five intellectual tasks: goal formulation, trend description, factor analysis, projection of future decisions, and the invention of alternatives." 75

74. In a nutshell, when joining the WTO, China committed to grant preferential treatment to auto-parts without fully understanding the contents of "auto-parts" and later was found to have violated WTO rules by revising the tariffs. For details of the case, see Appellate Body Report, China-Measures Affecting Imports of Automobile Parts, WT/DS339/AB/R, WT/DS340/AB/R \& WT/DS342/AB/R (Dec. $15,2008)$.

75. Reisman, Wiessner \& Willard, supra note 1, at 576. 